\title{
Developing affordable housing design for low income in Sana'a, Yemen
}

\begin{abstract}
Purpose: Housing costs are very high in Yemen compared with Middle East countries, which caused a shortage of housing supply especially for low-income groups. This paper aims to develop affordable housing design for people with low income and to examine their ability to afford houses in Sana'a, Yemen.

Design/methodology/approach: Two different questionnaires were used to achieve the study objectives. The first one was to examine the requirements and needs of low-income groups, while the second was to analyze the feedback of professionals in relevant housing authorities in Sana'a. An affordable house design methodology was used to design alternatives of lowincome housing in order to minimize cost and environmental impact while maximizing the social acceptability in housing projects.

Findings: The results show that the low-income group can afford new houses in Sana'a in consideration of the following: constructing multi-storey housing units such as apartment system through using the concrete frame structure and building the internal and external walls with concrete blocks with limited areas (65-120) square meters.

Originality/value: The findings could be used to improve housing affordability through housing policies in Yemen in order to decrease the housing shortage particularly for the lowincome group.
\end{abstract}

Keyword: Housing; Low pay; Prices; Yemen 